Available online: https://journals.researchsynergypress.com/index.php/ijebce/

International Journal of Entrepreneurship, Business and Creative Economy (IJEBCE)

ISSN 2775-3085 (Online) | 2775-3107 (Print)

Volume 1 Number 2 (2021): 12-20

\title{
Influence Service Quality and Tuition Fee on Student Satisfaction During The Handling of Covid-19 Outbreak
}

\author{
Dewi Murtiningsih', Widi Wahyudi ${ }^{1}$ \\ 1 Universitas Budi Luhur
}

\begin{abstract}
The purpose of the research is to find out service quality and tuition fees on student satisfaction (partially or simultaneously). The type of this research is explanatory research. The population used in research is all 5,594 students of Budi Luhur University. The sampling technique used is proportional sampling. The number of samples used in this research is 110 . SPSS is used as an analysis tool. The result of this research shows that service quality influences student satisfaction, tuition fee influences student satisfaction, and service quality and tuition fee simultaneously influence student satisfaction.
\end{abstract}

Keywords: Service Quality; Tuition Fee; Student Satisfaction

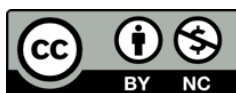

This is an open access article under the CC-BY-NC license.

\section{INTRODUCTION}

The covid-19 pandemic, which is happening right now, has shown its impact everywhere, not only in the economy sector but also in the education sector. Both central government and regional have released policy to dismiss all educational institutions, and all higher educational institutions or universities to apply online study. It is applied as an effort to cut off the coronavirus spread chain. The former face-to- face educational system, starting from the third week of March 2020 is changed into the online system, both for servicing and studying activity. The student service at Budi Luhur University also uses digital technology. Service such as research permit, and others, all uses digital technology. Bachelor students (S1) who are in their process of finishing thesis normally have to ask for research permit to BAAK, but since Covid-19 pandemic, those who need the permit can access it in BAAK menu, then click document, choose research permit.

This research will discuss about how is the service quality toward students of Budi Luhur University influences their satisfaction. The service in case is tuition fee online payment which is based on student's perception on filled questionnaire. It is analyzed to gather information about students' needs and expectation.

Gap in this research is: research result by Malik and Danis (2010) states that service quality does not influence student satisfaction, and this is contrary with the research result of Hasan et al., (2008), which states that service quality influences student satisfaction. Based on the research result inconsistency above, thus the researchers are interested in studying service quality, tuition fee and student satisfaction variables in different research populations, and also using different analysis tools. Based on the research gap elaborated before, the researchers decide to conduct this research with different object. The targeted respondents in this research is bachelor students (S1) at Budi Luhur University who are at least already in their second semester. Based on the reasons above, therefore they need to study more about "Analysis of Service Quality and Tuition Fee influence on Student Satisfaction". Based on the background explained above, there are several 
International Journal of Entrepreneurship, Business and Creative Economy (IJEBCE), Vol. 1 (2), 12-20

Influence Service Quality and Tuition Fee on Student Satisfaction During

The Handling of Covid-19 Outbreak

Dewi Murtiningsih, Widi Wahyudi

problems that can be identified, they are: Does service quality influence student satisfaction? Does tuition fee influence student satisfaction? Does service quality and tuition fee influence student satisfaction?

\section{LITERATURE REVIEW}

\section{Service Quality Influences Satisfaction}

Service quality is closely connected to customer satisfaction. Service quality gives a certain push to the customers to create strong relation with the company. In the long term, this kind of relation will make it possible for the company to clearly understand their customers' expectations and needs. Therefore, the company will be able to boost customer satisfaction in which company maximizes customer's enjoyable experience and minimizes the less enjoyable one (Tjiptono, 1996). If the service quality received by the customer is better or as expected, therefore the customer will be satisfied and tend to try again, and vice versa (Alma, 2007). The result of research conducted by Mulyono et al., (2007), Putra (2009) and Sutanto et al., (2014), and Yesenia and Siregar (2014) shows that service quality positively influences consumer satisfaction. Based on the result above, therefore the hypothesis of this research is:

H1: Service quality influences student satisfaction

\section{Tuition Fee Influences Student Satisfaction}

Other than academic service quality, tuition fee is also one of the factors that influences student satisfaction. This because tuition fee is related to the amount of money which is paid every semester and the knowledge that students gain during the study process. Wijaya (2012: 119) states that education fee is the basic or minimum price of educational service charged in certain educational service product. Research conducted by Suharyanto (2018) proves that tuition fee influences student satisfaction. Based on the previous research result, therefore the hypothesis of this research is:

H2: Tuition fee influences student satisfaction.

\section{Service Quality and Tuition Fee Influence Student Satisfaction}

Service quality is also the main factor that influences student satisfaction. Research result shows that service quality has a positive and significant influence on consumer satisfaction. Based on the result of research conducted by Mulyono et al., (2007), Putra (2009) and Sutanto et al., (2014), and also Yesenia and Siregar (2014), it proves that service quality positively influences consumer satisfaction. Moreover, the result of research conducted by Suharyanto (2018) shows that tuition fee influences student satisfaction. Based on those research results, therefore the hypothesis of this research is:

H3: Service quality and tuition fee influence student satisfaction.

\section{RESEARCH METHOD}

This research is explanatory research. The population in this research is all students using Budi Luhur University's service, in this case students in five faculties; Information Technology Faculty (FTI), Economy and Business Faculty (FEB), Communication Science Faculty (FIKOM), Engineering Faculty (FT), and Social and Political Science Faculty (FISIP) who are at least already in their second semester, students who already fill their Study Plan Card (KRSS) in even semester school year 2019/2020 numbering 5.594 in total. Sample in this research is 110 respondents. The number 110 is explained from the table below: 
International Journal of Entrepreneurship, Business and Creative Economy (IJEBCE), Vol. 1 (2), 12-20

Influence Service Quality and Tuition Fee on Student Satisfaction During

The Handling of Covid-19 Outbreak

Dewi Murtiningsih, Widi Wahyudi

Table 1. Number of Samples in Research

\begin{tabular}{|c|c|c|c|}
\hline Faculty & Amount & $\begin{array}{c}\text { Presents } \\
\%=\left(\begin{array}{c}\Sigma @ \mathrm{~F} / \Sigma \mathrm{TN}) \mathrm{X} \\
100 \%\end{array}\right.\end{array}$ & $\begin{array}{c}\text { Sample } \\
\mathrm{S}=\% \mathrm{X} \\
\Sigma \mathrm{SD}\end{array}$ \\
\hline FIT & 1822 & $33 \%$ & 36 \\
\hline FROM & 1636 & $29 \%$ & 32 \\
\hline FEB & 1278 & $23 \%$ & 25 \\
\hline FILIP & 610 & $11 \%$ & 12 \\
\hline FT & 248 & $4 \%$ & 5 \\
\hline $\begin{array}{c}\text { Total Number } \\
\text { (TN) }\end{array}$ & 5594 & $100 \%$ & 110 \\
\hline
\end{tabular}

Source: Data processed by yourself; SD: Sample Determination.

The sample collecting technique used is proportional sampling. The determination of the sample is determined by the slovin formula, so that the number is 100 , then $10 \%$ is added so that it becomes 110 . The reason for adding $10 \%$ is if there is a defect in the collection of the questionnaire, then the rest still meets the minimum sample size rule. Data is obtained from questionnaire given out beforehand, the scale used in the questionnaire is 1-5. The collected respondent data is processed for validity and reliability first. It is said to be valid if the corrected total item cileration value is greater than 0.3 (Masrun in solimun, 2002) and is said to be reliable if the Cronbach alpha value is greater than 0.6 (Maholtra, 1996) after that Data is analyzed using linear regression with software SPSS Version 22.

\section{FINDINGS AND DISCUSSION}

\section{Normality Test}

Normality test for each variable in this research is done using graph analysis Normal P-Plot. The normality P-Plot testing using Normal P-Plot can be said normal if the picture is distributed with lots of data scattering around the diagonal line and its distribution is in the same direction as the diagonal line.

Figure 1. Graph of Student Satisfaction Normal P-Plot

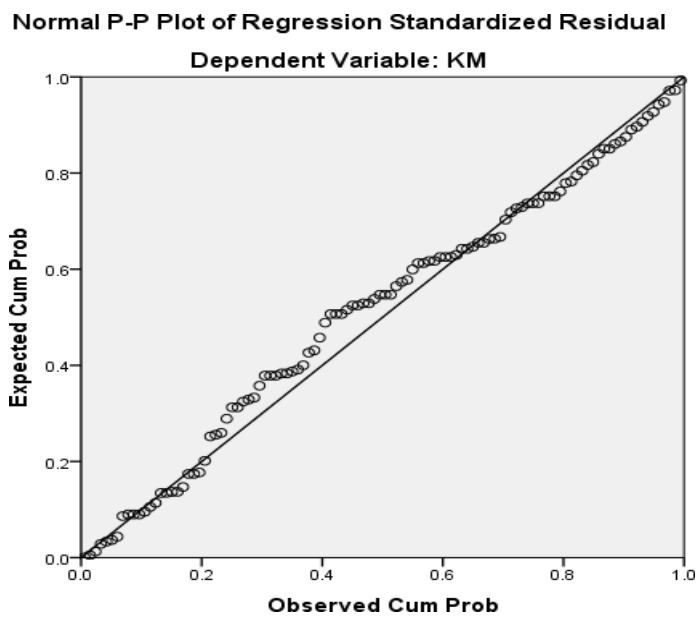

Source : Result of Output SPSS 22

On Figure 1, it can be seen from the SPSS output result of Normal P-Plot that the distribution of the data dots is scattering around the diagonal line, and its distribution is in the same direction as the diagonal line. Therefore, it can be said that the data on variable student satisfaction is normally distributed. 
International Journal of Entrepreneurship, Business and Creative Economy (IJEBCE), Vol. 1 (2), 12-20 Influence Service Quality and Tuition Fee on Student Satisfaction During

The Handling of Covid-19 Outbreak

Dewi Murtiningsih, Widi Wahyudi

\section{Multicollinearity Test}

Multicollinearity Test purpose is to test whether correlation between independent variables is found in regression model. In a good regression model, no correlation between independent variables should be found. Because if there is a correlation between independent variables, it can cause similarity within those variables. To say that there is no multicollinearity problem if the VIF between independent variables is no more than 10 , and the Tolerance value is not less than 0.1. The result of data processing using SPSS 22 is as follows:

Table 2. Result of Multicollinearity Test

Coefficients

\begin{tabular}{|c|c|c|c|c|c|c|c|}
\hline \multirow[t]{2}{*}{ Model } & \multicolumn{2}{|c|}{$\begin{array}{l}\text { Unstandardized } \\
\text { Coefficients }\end{array}$} & \multirow{2}{*}{$\begin{array}{c}\begin{array}{c}\text { Standardize } \\
\text { d } \\
\text { Coefficients }\end{array} \\
\text { Beta }\end{array}$} & \multirow[t]{2}{*}{$\mathrm{t}$} & \multirow[t]{2}{*}{ Sig. } & \multicolumn{2}{|c|}{$\begin{array}{l}95,0 \% \text { Confidence } \\
\text { Interval for B }\end{array}$} \\
\hline & B & $\begin{array}{l}\text { Std. } \\
\text { Error }\end{array}$ & & & & $\begin{array}{l}\text { Lower } \\
\text { Bound }\end{array}$ & $\begin{array}{l}\text { Upper } \\
\text { Bound }\end{array}$ \\
\hline (Constant & -4.040 & 1.478 & & -2.734 & .007 & -6.970 & -1.111 \\
\hline SQ & .405 & .060 & .526 & 6.715 & .000 & .286 & .525 \\
\hline$B$ & .243 & .051 & .375 & 4.782 & .000 & .143 & .344 \\
\hline
\end{tabular}

Dependent Variable: KM

Source: Result of Output SPSS 22

On the output result in Table 2, each independent variable has:

1. Service Quality

Tolerance: 0.526 bigger than 0.1

VIF : 6.715 less than 10

2. Tuition Fee

Tolerance: 0.375 bigger than 0.1

VIF : 4.782 less than 10

Therefore, it can be said that there is no multicollinearity happened between independent variables in the regression model. Thus, the data can be used for further research.

\section{Heteroscedasticity Test with Spearman's Rho Correlation Method}

Heteroscedasticity Test using Spearman's Rho Correlation Coefficient test technique is to correlate the independent variables with its residual. The test is using significance level 0.05 with 2 sides test. If the significance of the relation between independent variable with its residual is more than 0.05 , therefore it can be concluded that there is no heteroscedasticity problem.

Table 3. The Result of Heteroscedasticity Test using Spearman's Rho Correlation Method

\begin{tabular}{|ll|r|r|r|}
\hline & & \multicolumn{1}{|c|}{ KM } & \multicolumn{1}{|c|}{ SQ } & \multicolumn{1}{c|}{ B } \\
\hline \multirow{4}{*}{ Pearson Correlation } & KM & 1.000 & .809 & .771 \\
& SQ & .809 & 1.000 & .753 \\
Sig. (1-tailed) & $\mathrm{B}$ & .771 & .753 & 1.000 \\
& $\mathrm{KM}$ &. & .000 & .000 \\
& $\mathrm{SQ}$ & .000 & .000 & .000 \\
& $\mathrm{~B}$ & .000 & .000 &.
\end{tabular}


International Journal of Entrepreneurship, Business and Creative Economy (IJEBCE), Vol. 1 (2), 12-20

Influence Service Quality and Tuition Fee on Student Satisfaction During

The Handling of Covid-19 Outbreak

Dewi Murtiningsih, Widi Wahyudi

\begin{tabular}{lll|l|l|l|}
\hline & KM & 110 & 110 & 110 \\
$\mathrm{~N}$ & $\mathrm{SQ}$ & 110 & 110 & 110 \\
& $\mathrm{~B}$ & 110 & 110 & 110 \\
\hline
\end{tabular}

Source: Output SPSS 22.

From the output result in the Table 3. above, we can see the correlation between service quality and tuition fee variable. Unstandardized Residual has significance value Sig. (1-tailed) bigger than 0.05 . Since the significance value is bigger than 0.05 , it can be concluded that there is no heteroscedasticity problem.

\section{Correlation Analysis}

Pearson correlation test is conducted to find out how intense is the relation between service quality, tuition fee and student satisfaction variables, to see whether the correlation coefficient value ranging between 0 to 1 , or in other words if it is closer to 1 then it means it has strong relation, if it is closer to 0 then it is weak. To see correlation coefficient value, it can be helped using SPSS 22 program which produce output as follows:

Table 4. Pearson Correlation Correlations

\begin{tabular}{|c|c|c|c|c|}
\hline & & $\overline{S Q}$ & B & KM \\
\hline & Pearson Correlation & 1 & $.753^{* *}$ & $.809^{* *}$ \\
\hline \multirow[t]{3}{*}{ SQ } & Sig. (2-tailed) & & .000 & .000 \\
\hline & $\mathrm{N}$ & 110 & 110 & 110 \\
\hline & Pearson Correlation & $.753^{* *}$ & 1 & $.771^{* *}$ \\
\hline \multirow[t]{3}{*}{ B } & Sig. (2-tailed) & .000 & & .000 \\
\hline & $\mathrm{N}$ & 110 & 110 & 110 \\
\hline & Pearson Correlation & $.809^{* *}$ & $.771^{* *}$ & 1 \\
\hline \multirow[t]{2}{*}{ KM } & Sig. (2-tailed) & .000 & .000 & \\
\hline & $\mathrm{N}$ & 110 & 110 & 110 \\
\hline
\end{tabular}

Table 4. above shows the intensity of the relation between service quality variable and studentsatisfaction which is 0.809 . Therefore, it can be concluded that the intensity of the relation between service quality and tuition fee is quite high since the coefficient value is ranging in between $0.80-1.00$. Thecoefficient number also shows a positive number, which means that if the quality of service is improved, then the student satisfaction number will also improve. In contrary, if service quality is lowered, thenstudent satisfaction will also decrease. In the column Sig. (2-tailed) there is 0.000 probability ( 0.000 issmaller than 0.05$)$, it means that there is a relation between service quality and student satisfaction.

Based on Table 4. above, it shows the intensity of the relation between tuition fee variable andstudent satisfaction number 0.771 . It can be concluded that the intensity of correlation between tuition fee and student satisfaction is quite high since the coefficient value is ranging between 0.4 0.799. Coefficient number also shows positive number which means that if tuition fee is increased, then student satisfaction will also be improved. In contrary, if tuition fee is decreased, then student satisfaction will also be decreased. In the column Sig. (2-tailed) there is 0.000 probability $(0.000$ is less than 0.05), it means there is the relation between tuition fee and student satisfaction. 
International Journal of Entrepreneurship, Business and Creative Economy (IJEBCE), Vol. 1 (2), 12-20

Influence Service Quality and Tuition Fee on Student Satisfaction During

The Handling of Covid-19 Outbreak

Dewi Murtiningsih, Widi Wahyudi

\section{Multiple Linear Regression Analysis}

The purpose of multiple linear regression is to test the influence of one variable to another and see whether the result value of the studied variable is positive or negative. A hypothesis test is used to examine the influence of service quality and tuition fee on student satisfaction.

Table 5. Result of Multiple Linear Regression Analysis - Enter Method

\begin{tabular}{|c|c|c|c|c|c|c|}
\hline \multirow{2}{*}{\multicolumn{2}{|c|}{ Model }} & \multicolumn{2}{|c|}{ Unstandardized Coefficients } & \multirow{2}{*}{$\begin{array}{c}\begin{array}{c}\text { Standardized } \\
\text { Coefficients }\end{array} \\
\text { Beta } \\
\end{array}$} & \multirow[t]{2}{*}{$\mathrm{t}$} & \multirow[t]{2}{*}{ Sig. } \\
\hline & & B & Std. Error & & & \\
\hline \multirow{3}{*}{1} & (Constant) & -4.040 & 1.478 & & -2.734 & .007 \\
\hline & SQ & .405 & .060 & .526 & 6.715 & .000 \\
\hline & B & .243 & .051 & .375 & 4.782 & .000 \\
\hline
\end{tabular}

a. Dependent Variable: KM

Source: Output SPSS 22 Result

Based on Table 5. above, the formed regression equation is:

$\mathrm{Y}=\alpha+\beta 1 \mathrm{X} 1+\beta 2 \mathrm{X} 2+\beta 3 \mathrm{X} 3+e$

$\mathrm{Y}=-4.040+0.405 \mathrm{X} 1+0.243 \mathrm{X} 2$

In which:

$\mathrm{Y}=$ Student Satisfaction

$\mathrm{X} 1$ = Variable Service Quality

$\mathrm{X} 2$ = Variable Tuition Fee

$\alpha=$ Constant

$\beta 1=$ First Regression Coefficient Number

$\beta 2=$ Second Regression Coefficient Number

$\mathrm{e} \quad=$ Standard Error

From the regression equation above, it can be interpreted:

1. Constant -0.4040 means: If the value of service quality and tuition fee is 0 or does not influence, therefore the value of student satisfaction is -4.040 .

2. Regression coefficient of service quality variable $(\beta 1)$ is positive, numbering 0.405 . It can be said that every 1 service quality escalation, it can enhance student satisfaction by 0.405 .

3. Regression coefficient of tuition fee variable $(\beta 2)$ is positive, numbering 0.243 . It can be said that every 1 tuition fee escalation, it can enhance student satisfaction by 0.243 .

\section{Determination Coefficient $\left(\mathbf{R}^{2}\right)$}

Determination Coefficient is used to find out the amount of contribution of service quality and tuition fee variable on student satisfaction. On Table 6. above, it can be seen that the R-value is 0.845 approaching number 1 . Therefore, it can be concluded that the relation between service quality and tuition fee with student satisfaction is quite close. Determination coefficient or Adjusted R Square is 0.715 or $71.5 \%$. The number means $71.5 \%$ of student satisfaction is influenced by service quality and tuition fee, while the rest $28.5 \%$ is influenced by other factors 
International Journal of Entrepreneurship, Business and Creative Economy (IJEBCE), Vol. 1 (2), 12-20 Influence Service Quality and Tuition Fee on Student Satisfaction During

The Handling of Covid-19 Outbreak

Dewi Murtiningsih, Widi Wahyudi

which are excluded in this research. Std Error of the Estimate 2.407, means that the number of errors which can happen in prediction student satisfaction is 2.40 .

Table 6. Determination Coefficient

\begin{tabular}{|l|r|r|r|r|}
\hline Model & $\mathrm{R}$ & $\mathrm{R}$ Square & $\begin{array}{c}\text { Adjusted R } \\
\text { Square }\end{array}$ & $\begin{array}{c}\text { Std. Error of the } \\
\text { Estimate }\end{array}$ \\
\hline 1 & $.845^{\mathrm{a}}$ & .715 & .709 & 2.407 \\
\hline \multicolumn{2}{|r}{ Predictors: (Constant), B, SQ }
\end{tabular}

Dependent Variable: KM Output SPSS 22 Results

\section{Coefficient Partial Hypothesis Test (t-test)}

Coefficient Partial Hypothesis Test (t-test) is conducted to find out whether independent variable partially influences dependent variable. A partial test is conducted by comparing $t$ count with $t$ table, thus it is often called t-test. Degree of Freedom on t-test is $n-k-1$ where $n$ (number of data) and $\mathrm{k}$ (number of independent variable).

Table 7. Coefficient Partial Hypothesis Test (t-test)

\begin{tabular}{|c|c|c|c|c|c|c|}
\hline \multirow{2}{*}{\multicolumn{2}{|c|}{ Model }} & \multicolumn{2}{|c|}{ Unstandardized Coefficients } & \multirow{2}{*}{$\begin{array}{c}\begin{array}{c}\text { Standardized } \\
\text { Coefficients }\end{array} \\
\text { Beta } \\
\end{array}$} & \multirow[t]{2}{*}{$\mathrm{t}$} & \multirow[t]{2}{*}{ Sig. } \\
\hline & & B & Std. Error & & & \\
\hline \multirow{3}{*}{1} & (Constant) & -4.040 & 1.478 & & -2.734 & .007 \\
\hline & SQ & .405 & .060 & .526 & 6.715 & .000 \\
\hline & B & .243 & .051 & .375 & 4.782 & .000 \\
\hline
\end{tabular}

a. Dependent Variable: KM

Source : Output SPSS 22 Result

From Table 7 above, it can be concluded that:

1. Service quality variable ( $\mathrm{t}$ count $=6.715 ; \mathrm{Sig}=0.000$ ), therefore $\mathrm{HO}$ is rejected, $\mathrm{Ha}$ is accepted. Significance is less than 0.05 (0.000 is less than 0.05), therefore Ha is accepted, $\mathrm{HO}$ is rejected. Thus, it can be concluded that service quality variable partially influences student satisfaction.

2. Tuition fee variable ( $\mathrm{t}$ count $=4.782$; Sig $=0.000$ ), therefore $\mathrm{H} 0$ is rejected, Ha is accepted. Significance is less than $0.05(0.000$ is less than 0.05$)$, therefore Ha is accepted, HO is rejected. Thus, it can be concluded that tuition fee variable partially influences student satisfaction.

\section{Coefficient Simultaneous Hypothesis}

Regression coefficient simultaneous test is conducted to find out whether independent variable simultaneously and significantly influences dependent variable. The equation test is simultaneously conducted by comparing $\mathrm{F}$ count and $\mathrm{F}$ table. The probability value of $\mathrm{F}$ count (sig) on Table 4 is 0.000 , smaller than the error level $(0.05)$, therefore it can be concluded that the linear regression model estimated is feasible to be used to explain the influence of service quality and tuition fee on student satisfaction.

Table 8. Coefficient Simultaneous Hypothesis Test (F Test) 
International Journal of Entrepreneurship, Business and Creative Economy (IJEBCE), Vol. 1 (2), 12-20

Influence Service Quality and Tuition Fee on Student Satisfaction During

The Handling of Covid-19 Outbreak

Dewi Murtiningsih, Widi Wahyudi

\begin{tabular}{|c|c|c|c|c|c|c|}
\hline \multicolumn{7}{|c|}{ ANOVA } \\
\hline & & $\begin{array}{l}\text { Sum of } \\
\text { Squares }\end{array}$ & $\mathrm{df}$ & Mean Square & $\mathrm{F}$ & Sig. \\
\hline \multirow{3}{*}{1} & Regression & 1553.657 & 2 & 776.829 & 134.062 & .000 \\
\hline & Residual & 620.016 & 107 & 5.795 & & \\
\hline & Total & 2173.673 & 109 & & & \\
\hline
\end{tabular}
a. Dependent Variable: KM
b. Predictors: (Constant), B, SQ
Source : Output SPSS 22 Result

\section{Discussion}

\section{The Influence of Service Quality on Student Satisfaction}

Analysis result shows that service quality influences satisfaction of all five faculties students at Budi Luhur University, Jakarta. Empirical fact shows that indicator of service quality variable with highest average value, which is tangible indicator content with value 3.87 , which is interpreted with item Staff and lecturer in the five faculties at Budi Luhur University, Jakarta dressed neatly is able to satisfy its students. This research is in line with the research conducted by Mulyono et al., (2007), Putra (2009) and Sutanto et al., (2014), and Yesenia and Siregar (2014) which result proves that service quality positively influences consumer satisfaction.

\section{The Influence of Tuition Fee on Student Satisfaction}

Analysis result shows that tuition fee influences student satisfaction of all five faculties students at Budi Luhur University, Jakarta. Empirical fact shows that indicator of tuition fee variable with highest average value which is payment procedure with value 4.25 , which is reflected with item tuition fee payment at Budi Luhur University can be paid in installments is able to satisfy the student in continuing their next semester study. This research is in line with the research conducted by Suharyanto (2018) which result states that tuition fee influences student satisfaction.

\section{Research Result Interpretation Simultaneously}

Based on the research conducted, the result shows that service quality and tuition fee have a positive influence on satisfaction of all five faculties students of Budi Luhur University, Jakarta with Sig. value 0.000 in which smaller than the standardized error level 0.05 (0.000 less than 0.05 ). Therefore, it can be concluded that the estimated linear regression model is feasible to be used to explain the influence of service quality and tuition fee on student satisfaction. This research is in line with the research conducted by Mulyono et al., (2007), Putra (2009) and Sutanto et al., (2014), and also Yesenia and Siregar (2014) which proves that service quality positively influences consumer satisfaction. Moreover, the research result of Suharyanto (2018) shows that tuition fee influences student satisfaction. 
International Journal of Entrepreneurship, Business and Creative Economy (IJEBCE), Vol. 1 (2), 12-20

Influence Service Quality and Tuition Fee on Student Satisfaction During

The Handling of Covid-19 Outbreak

Dewi Murtiningsih, Widi Wahyudi

\section{CONCLUSION}

Based on the analysis and discussion on the previous chapter, it can be concluded that: service quality influences student satisfaction; tuition fee influences student satisfaction; service quality and tuition fee influence student satisfaction.

\section{LIMITATION \& FURTHER RESEARCH}

Suggestion for next researchers are as follow: For the next research to conduct questionnaire pre-sampling test because in this research, there are still some indicators with duality, which means one indicator can measure two variables; Samples in this research originated only from one institution, therefore for the next research, sample should be added by broadening the number of institution chose as research object; This research is conducted on service institution or university, therefore research on different population such as service company, trading and manufacturing sector or financial institution other than bank needs to be conducted; The analysis tool used in this research is SEM-PLS, other analysis tools such as SEM_AMOS, SPSS, etc. are suggested to be used.

\section{REFERENCES}

Alma, Buchari. (2007). "Strategi Pemasaran Jasa Pendidikan Tinggi”, Bunga Rampai Strategik, Manajemen Bisnis berbasis hasil penelitian, Cetakan Kesatu, April 2007, Alfabeta, Bandung, p. 1 13.

Hasan, H., \& Illias, A. (2008). Service Quality and Student Satisfaction: A Case Study at Private Higher Education Institutions. International Business Research, Vol.1 No. 3, 163-175.

Malik, M. E., Danish, R. Q., \& Usman, A. (2010). The Impact of Service Quality on Students' Satisfaction in Higher Education Institutes of Punjab. Journal of Management Research, Vol.2 No.2, $1-11$.

Maholtra, Naresh K., (1996), Marketing Research, Third Edition, Prentice-Hall, New Jersey. Mulyono, Bayu Hadyanto; Yoestin, Rini Nugraheni; Musofa Kamal. (2007). Analisis Pengaruh

Kualitas Produk dan Kualitas Layanan Terhadap Kepuasan Konsumen (Studi Kasus Pada Perumahan Puri Mediterania Semarang). Jurnal Studi Manajemen Dan Organisasi. Vol.4; No. 2. Juli. Halamam 91.

Putra, I Wayan Jaman Adi. 2009. Pengaruh Kualitas Pelayanan Terhadap Kinerja Kerelasian Nasabah. Jurnal Ekonomi Dan Bisnis. No.2. Juli.

Solimun. (2002). Multivariate Analysis Sem, Lisrel dan Amos, Aplikasi Manajemen, Ekonomi Pembangunan, Psikologi, Sosial, Kedokteran dan Agrokompleks. Malang: UM.

Suharyanto. (2018). Dampak Kualitas Pelayanan Dan Biaya Kuliah Terhadap Kepuasan Mahasiswa Universitas X Bandung. Ensais. Vol.1; No.1. Mei.

Sutanto, J.E; Charly Honhdiyanto; Hari Minantyo. (2014). The Influence Service Quality, Product Quality To Customer Satisfaction (A Case Study At Modern Ritell In East Java). The First International Conference an Entrepreneurship.

Tjiptono, Fandy. (1996). Manajemen Jasa. Yogyakarta: Andi Offset.

Yessenia Dan Siregar. (2014). Pengaruh Kualitas Layanan Dan Produk Terhadap Kepuasan Serta Loyalitas Pelanggan Kentucky Fried Chiken Di Tangerang Selatan. Jurnal Manajemen Dan Organisasi. Vol 5 (3). 184-199.

Wijaya, D. (2012). Pemasaran Jasa Pendidikan. Jakarta: Salemba. 